\title{
The Influence of Cover on the Water Quality and Suspended Solids Under the Simulated Rainfall Condition
}

\author{
Syed Muzzamil Hussain $\operatorname{Shah}^{1}$, Khamaruzaman Wan Yusof ${ }^{1}$, Zahiraniza Mustaffa $^{1}$ \& Ahmad Mustafa Hashim $^{1}$ \\ ${ }^{1}$ Universiti Teknologi PETRONAS, Perak, Malaysia \\ Correspondence: Syed Muzzamil Hussain Shah, Block 13 Civil Engineering Department, Universiti Teknologi \\ PETRONAS, Perak, Malaysia. Tel: 60-11-1572-9650. E-mail: syedmuzzamil1986@gmail.com
}

Received: April 22, 2013

doi:10.5539/mas.v7n7p42
Accepted: June 5, 2013 Online Published: June 18, 2013

URL: http://dx.doi.org/10.5539/mas.v7n7p42

\begin{abstract}
Highway embankments could be of equal importance when compared with the agricultural lands for the production of sediments as it carries the detached soil particles in the water which flows over land in the form of surface runoff. The downstream sedimentation from agricultural activities has always been highlighted, whereas the road related impacts are considered trivial. This paper analyzes the results, obtained from a full scale test with rainfall simulation on the fully grass covered surface (Plot-I) and the exposed soil surface (Plot-II) for the inevitable issue of water quality and turbidity affected by the soil erosion. The study was conducted on a filled embankment having slope angle of $30^{\circ}$ which observed a marginal difference under the rainfall intensity of 40 $\mathrm{mm} /$ hour for both the plots. The results obtained recommend fully grass covered surface to mitigate this problem to an extent. The maximum turbidity and suspended particle values for Plot-I were found to be 75 (NTU) and $11.3(\mathrm{mg} / \mathrm{L})$ whereas, for Plot-II the values were found to be $1631.5(\mathrm{NTU})$ and $52.3(\mathrm{mg} / \mathrm{L})$ respectively.
\end{abstract}

Keywords: bare soil, grass cover, suspended particles, turbidity

\section{Introduction}

When the land area is developed, the construction phase exposes the earth which contributes to the storm water pollution by means of surface runoff during a rainfall event. This allows the sediments to enter into the river which degrades the water quality, irrigation canals, lakes, reservoirs, and etc. The measurement of water quality is termed as total suspended solids (TSS) whose removal is very important for the clarity of water and for managing the natural resources of a water body. Whereas, turbidity is the sediment concentration in flow which relates to the darkness of water caused by the presence of suspended solids (Yahyapour, 2013).

To have a clear vision about the sediment concentration in the flow and the measurement of the water quality, it is necessary to understand the way how the soil gets eroded and deposited to basins which is illustrated in Figure 1.

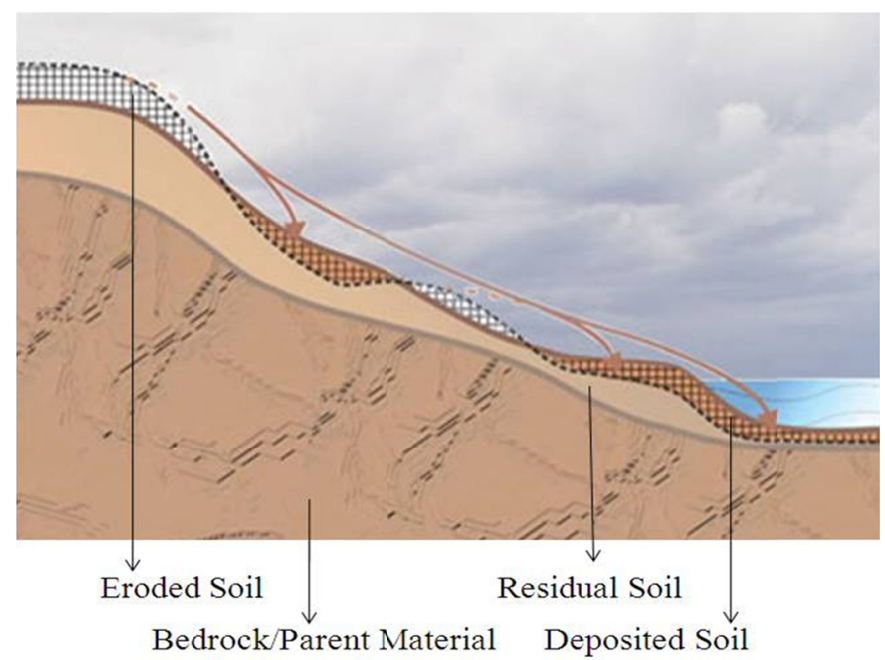

Figure 1. Soil deposition in the basins (Preuss, 2007) 
The improvement of agricultural practices including the soil conservation measures has been traditionally focused in many tropical countries to mitigate on-site soil detachment and off-site sedimentation. However, the potential importance of the roads in accumulating runoff and soil erosion is well recognized but rarely quantified (Rijsdijk, 2007). For developing a humid tropical region, it requires knowledge on rainfall and runoff response before implementing the engineering practices to minimize the erosion process (Leong, 2007). Soil detachment is an unavoidable process which cannot be disregarded (Bakr, 2012). It is such a concern for which it is adequate to say "think globally, act locally" (Toy, 2002) as it leads to the process of sedimentation which is responsible for the higher turbidity rates and the suspended particles in the water channel (Chou, 2010). However, for preserving the global environment it is necessary to understand the relation between land cover and soil erosion.

The concentration of contaminants in the water channel is mainly due to the process of erosion, which is also responsible for the devastation of the nutrient-rich top soil for which it is suggested to treat the diffused pollutants at its origin (Deletic, 2001). Human activities and natural processes are both responsible for the potential susceptibility of an area to erosion (Ekholm, 2012) which is responsible for several negative affects among which the most vital are worsening of the road utilities, increment in the maintenance cost and reconstruction, loss of soil productivity, and deposition in the water channel leading to its instability (Sekitar, 1996).

Vegetated areas are best recommended to trap the suspended sediments in the flow (Yahyapour, 2013). However, a study negates that planting grass is ineffective to shelter the soil from erosion (Wilson, 2012). Although, land cover has been favored by several studies against erosion as it influence the runoff intensity which restricts the flow of the detached soil particles to the water channel (Peng, 2012). Comparatively, in reducing the soil loss herbaceous vegetation is suggested to be more protective than the woody vegetation (Bert, 2007) as it allows the water to penetrate through the soil pores which decelerates the runoff velocity (Deletic, 2001). It rapidly grows with a dense root system which grips the soil particles from detachment (De Baets, 2006) and softens the kinetic energy of the rain drop which shelter the soil from its direct impact (Zuazo, 2011). Its implication is therefore suggested to be much more reliable conservation measure than the artificial methods (Samani, 2002).

The focus of the study is the bare highway embankments and unprotected slopes which possesses great threat towards water quality and the channel storage capacity. Soil erosion relates to the impact of rain drop which is the most significant factor as it loosens, erodes and removes the soil particles from their place of origin. This affects the soil geometry and worsens the soil arrangement, resulting in its failure. It allows the detached particles to flow with the surface runoff which then reaches the rivers and the process of deposition occurs.

Primarily, the objective of the study is to observe the influence of cover in reducing the turbidity and suspended particles values by comparing it with the bare soil surface, for which the water samples were collected at different time intervals from the runoff generated by the simulated rainfall condition.

Table 1 shows an overview of the previous studies describing problems caused by the deposited soil in the stream channels. Few of the major problems associated with the silt deposition are assembled below.

Table 1. Problems accountable to silt deposition

\begin{tabular}{|c|c|c|}
\hline Author and year & Problem & Description \\
\hline (Chou et al., 2010) & Severe precipitation & $\begin{array}{l}\text { Tahan River of northern Taiwan faced a severe } \\
\text { precipitation of the last } 40 \text { years with the peak inflow of } \\
8500 \mathrm{~m}^{3} \mathrm{sec}^{-1} \text { and the total runoff volume of } 700 \text { million } \\
\mathrm{m}^{3} \text { which was three times more than the capacity of the } \\
\text { reservoir. Majority of the landslides were reported to be } \\
\text { collapsed which flushed around } 28 \text { million } \mathrm{m}^{3} \text { of the } \\
\text { sediments into the reservoir which raised the turbidity of } \\
\text { the steam by } 100,000 \text { NTU. }\end{array}$ \\
\hline (Ziegler et al., 1997) & Unpaved roads & $\begin{array}{l}\text { Unpaved roads are significant source of soil erosion } \\
\text { which is responsible for low infiltration rates. It leads to } \\
\text { the increased sediment loads which not only degrade the } \\
\text { landscape but it also influx the toxic contaminants and } \\
\text { disruptive nutrients to the water channel affecting the } \\
\text { water quality. }\end{array}$ \\
\hline
\end{tabular}


(Cornish et al., 2001) Forest harvesting

(Yahyapour et al., 2013)

Detrimental impact on fauna and flora

Toxic contaminants
The road-stream connectivity is suggested to be the most important factor in delivering sediments to the catchment. Forest harvesting in the absence of roads generally reduced turbidity levels if precautionary measures are adopted during harvesting.

From the construction site the non point pollution contributes to the storm water pollution and enters the river which affects the aquatic and wildlife.

The storm water runoff carries not only the sediments but also the toxic chemicals associated with the roads and vehicles are taken into the storm water drainage system.

\section{Material and Method}

The site location and rainfall data, description of the study area, and the experimental procedures used for determining the turbidty rates and the total suspended soilds have been discussed in this section.

\subsection{Site Location and Rainfall Data}

The study was performed at Universiti Teknologi PETRONAS, Malaysia. A full scale test was performed on a fully grass covered surface (Plot-I) and a bare soil surface (Plot-II), analogous to filled embankments to observe the behavior of these plots against water quality and turbidity under the simulated rainfall intensity of 40 $\mathrm{mm} /$ hour (average rainfall intensity for the Perak State, Malaysia). The rainfall data was obtained and analyzed from Meteorological Department Malaysia for the year 2005 to 2011. The study was conducted for the slope angle of $30^{\circ}$ with the gradient of 1 on 1.5 (representing typical constructed road side slopes).

\subsection{Description of the Study Area}

Figure 2 shows the details of the existing site location. Plot-I and Plot-II were covered with plastic to hinder the effects of natural rainfall while running the experiments. The simulated rainfall condition modeled for this study was $40 \mathrm{~mm} /$ hour for which a flow meter was used to adjust the required rainfall intensity. The generated runoff was received in the designed container of known volume. The water samples were collected at different time intervals to study the presence of suspended particles and the water turbidity.

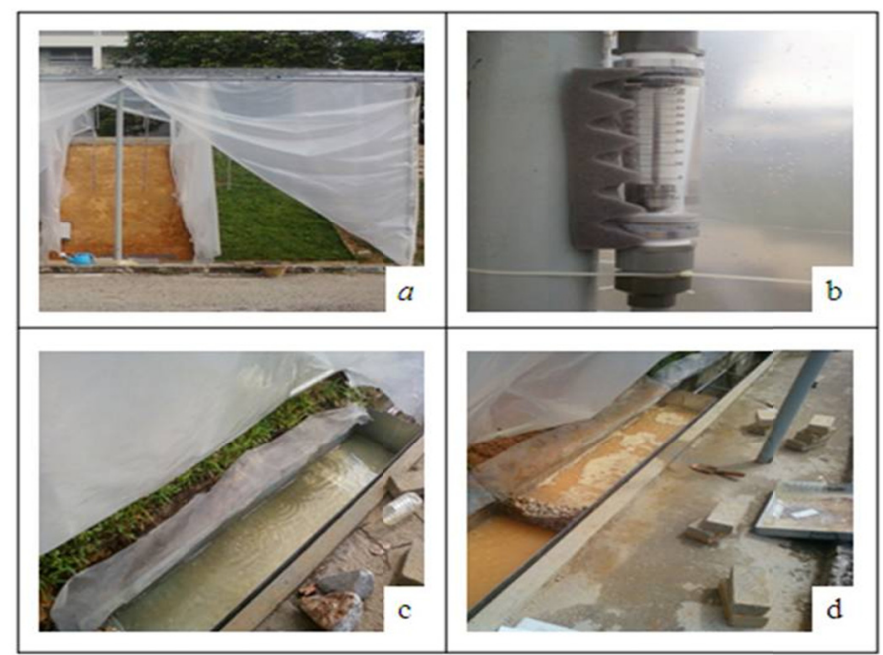

Figure 2. Description of the study area (a) site location of plot-I and plot-II, (b) flow meter, (c) and (d) water samples collected from Plot-I and Plot-II for assessing turbidity and suspended solids

\subsection{Experimental Procedures}

The samples collected during the experiment were quite turbid and the turbidity meter was unable to determine its range. However, from each sample $1 \mathrm{ml}$ of water was taken in to the graduated cylinder which was then mixed with $49 \mathrm{ml}$ of the distilled water (1 in 50 dilutions was used for sample analysis). Now from the graduated cylinder, $10 \mathrm{ml}$ of mixed sample was taken and placed into the glass cuvette which was then placed into the 
turbidity meter to determine the sample turbidity as shown in Figure 3 (a) and (b).

Figures 3 (c) and (d) show the method how suspended solids were determined. The filter papers were placed in the flask using the tweezers which were then washed with the distilled water and by applying the vacuum to the flask. The filter papers were gently removed and placed in the filter holders which were then labeled and taken into the oven for 24 hours at $105^{\circ} \mathrm{C}$. The filter papers were desiccated for 20 min and weighed $\left(\mathrm{W}_{1}\right) . \mathrm{Next}_{1} 10 \mathrm{ml}$ of the water sample (original turbid sample) was taken into the graduated cylinder which was then mixed with 90 $\mathrm{ml}$ of distilled water which gave a total of $100 \mathrm{ml}$. For each reading, three diluted samples were poured into the flask containing washed and dried filter papers. The filter papers containing suspended particles were then dried for 1 hour and placed in the desiccators for 20 min which were then weighed $\left(\mathrm{W}_{2}\right)$. The formula used for determining the total suspended solids (TSS) is given below.

$$
\mathrm{TSS}=\mathrm{W}_{2}(\mathrm{mg})-\mathrm{W}_{1}(\mathrm{mg}) / 0.1(\mathrm{~L})
$$

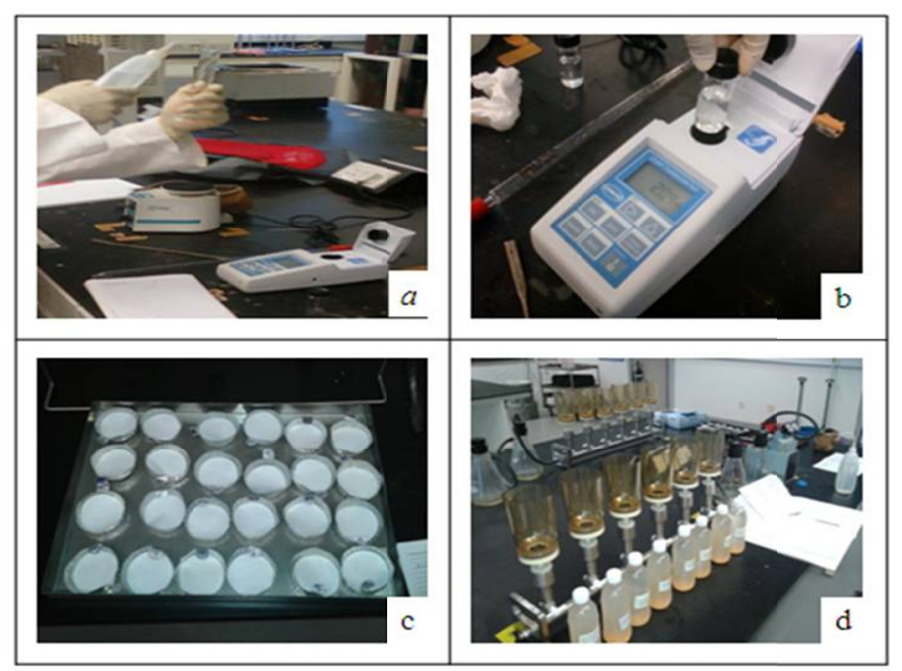

Figure 3. Experimental procedure (a) and (b) determination of turbidity, (c) and (d) determination of suspended solids

\section{Results}

The graphical representations of the results, attained by conducting the experiments are shown in this section.

\subsection{Turbidity}

Figure 4 shows the turbidity values obtained from Plot-I and Plot-II under the rainfall intensity of $40 \mathrm{~mm} / \mathrm{hour}$ at different time intervals of $15 \mathrm{~min}, 30 \mathrm{~min}, 45 \mathrm{~min}, 60 \mathrm{~min}, 75 \mathrm{~min}, 90 \mathrm{~min}, 105 \mathrm{~min}$, and 120min.

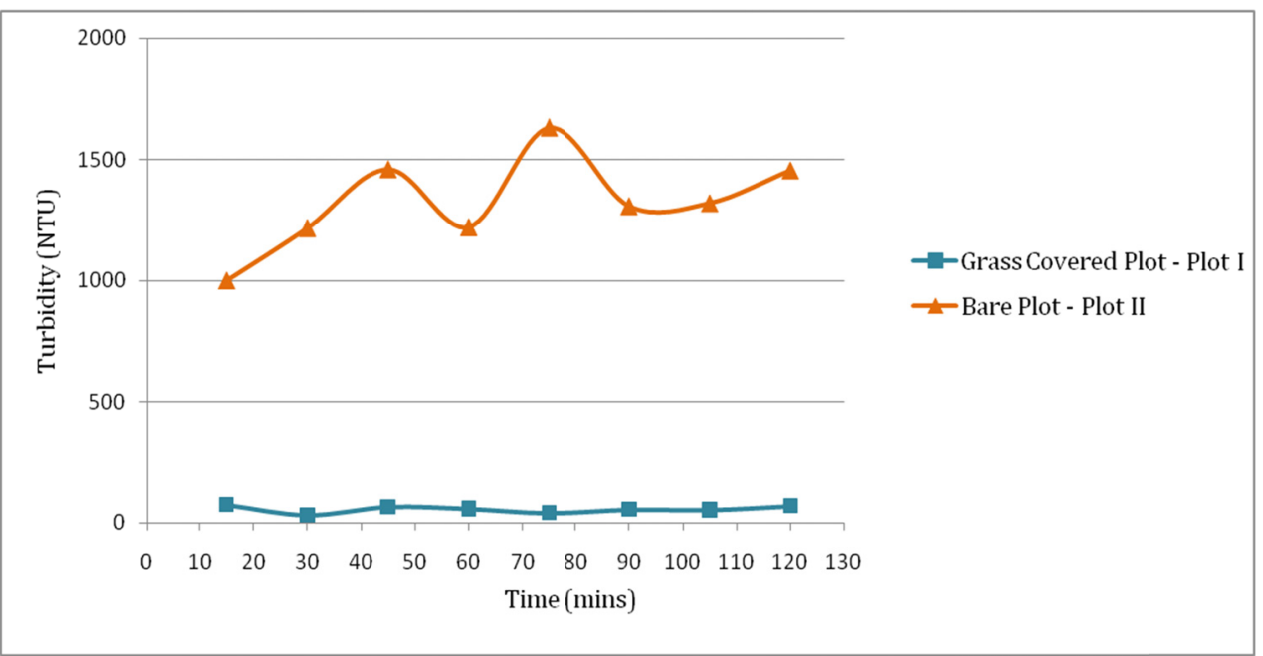

Figure 4. Turbidity values observed for Plot-I and Plot-II, under the Rainfall event of $40 \mathrm{~mm} / \mathrm{hour}$ 


\subsection{Suspended Solids}

Figure 5 shows the values of suspended solids obtained from Plot-I and Plot-II under the rainfall intensity of 40 $\mathrm{mm} /$ hour at different time intervals of $15 \mathrm{~min}, 30 \mathrm{~min}, 45 \mathrm{~min}, 60 \mathrm{~min}, 75 \mathrm{~min}, 90 \mathrm{~min}, 105 \mathrm{~min}$, and $120 \mathrm{~min}$.

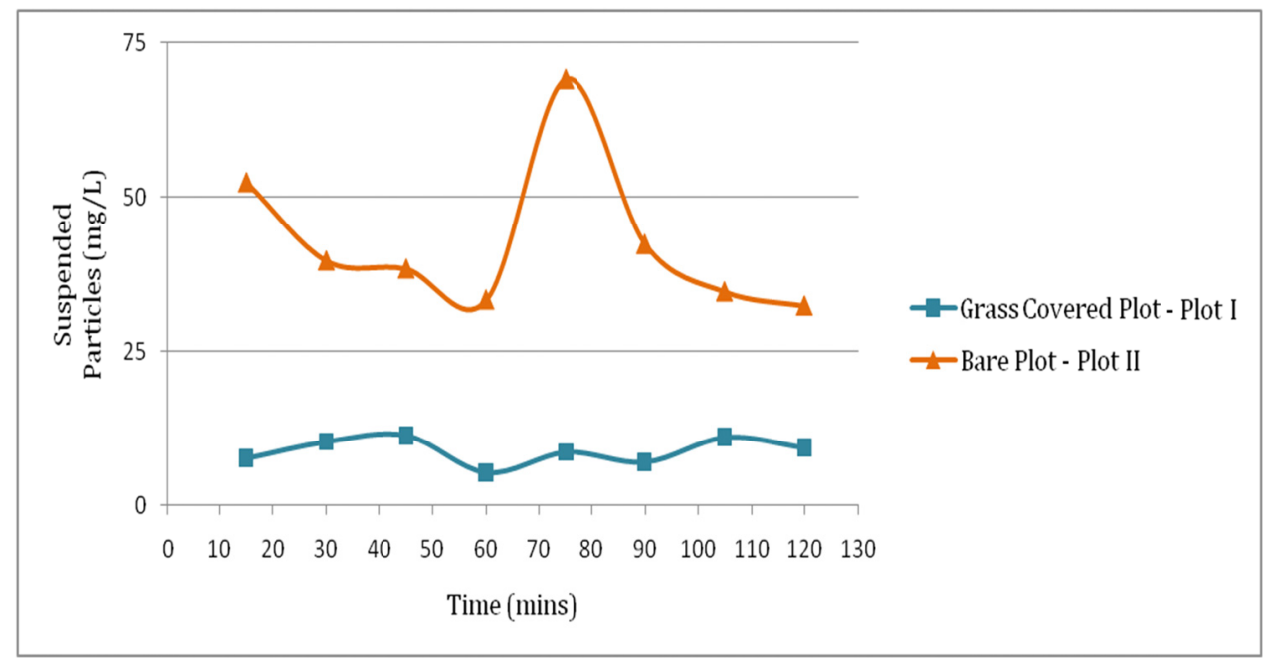

Figure 5. Suspended particles observed for Plot-I and Plot-II, under the Rainfall event of $40 \mathrm{~mm} /$ hour

\section{Discussion}

The maximum value obtained for turbidity under the rainfall event of $40 \mathrm{~mm} /$ hour from Plot-I was 70 (NTU). For Plot-II, the value was observed to be 1631.5 (NTU) which was approximately 22 times more than that of Plot-I. The maximum value obtained for suspended particles under the rainfall event of $40 \mathrm{~mm} /$ hour from Plot-I was $11.3(\mathrm{mg} / \mathrm{L})$. For Plot-II, the value was observed to be $69(\mathrm{mg} / \mathrm{L})$ which was nearly 6 times more than that of Plot I. The graph for both turbidity and suspended particles were not consistent because the soil eroded at different rates at different intervals of time.

This study emulates condition of newly constructed road embankments which usually remain bare after the construction. The study shows a marginal difference in the results for the small plot area of 2 meters by 6 meters only. However, in the real conditions the highway embankments may vary up to hundreds of kilometers for which the outcomes would surely be more intense if the bare soil surface is not covered. Therefore, it is recommended that once the embankments are newly constructed, it should be protected with the proper vegetative cover so that the rain drop impact does not allow the soil particles to detach from their point of origin. This helps mitigating the problems associated with silt deposition particularly originated from slope erosion. Although the full scale test was conducted for the rainfall data of Perak, Malaysia only and with native grass cover, but it can be observed under different rainfall intensities with the different vegetative covers, for different regions.

\section{Acknowledgements}

The author would like to thank Universiti Teknologi PETRONAS, Malaysia for the continuation of Graduate Assistantship and the URIF grant (code \# 22/12) for funding the project.

\section{References}

Bakr, N., Weindorf, D. C., Zhu, Y., Arceneaux, A. E., \& Selim, H. M. (2012). Evaluation of compost/mulch as highway embankment erosion control in Louisiana at the plot-scale. Journal of Hydrology, 468-469(25), 257-267. http://dx.doi.org/10.1016/j.jhydrol.2012.08.040

Bert, R. (2007). Book Review: ILandforming: An Environmental Approach to Hillside Development, Mine Reclamation and Watershed Restoration N by Horst J. Schor and Donald H. Gray. Hoboken, New Jersey: John Wiley \& Sons, 2007. Civil Engineering-ASCE, 77(10).

Chou, F. N. F., \& Wu, C. W. (2010). Reducing the impacts of flood-induced reservoir turbidity on a regional water supply system. Advances in Water Resources, 33(2), 146-157. http://dx.doi.org/10.1016/j.advwatres.2009.10.011

Coffin, A. W. (2007). From roadkill to road ecology: A review of the ecological effects of roads. Journal of 
Transport Geography, 15(5), 396-406. http://dx.doi.org/10.1016/j.jtrangeo.2006.11.006

Cornish, P. (2001). The effects of roading, harvesting and forest regeneration on streamwater turbidity levels in a moist eucalypt forest. Forest Ecology and Management, 152(1), 293-312. http://dx.doi.org/10.1016/S0378-1127(00)00611-3

De Baets, S., Poesen, J., Gyssels, G., \& Knapen, A. (2006). Effects of grass roots on the erodibility of topsoils $\begin{array}{lllll}\text { during } & \text { concentrated } & \text { Geomorphology, } & \text { 76(1-2), }\end{array}$ http://dx.doi.org/10.1016/j.geomorph.2005.10.002

Deletic, A. (2001). Modelling of water and sediment transport over grassed areas. Journal of Hydrology, 248(1), 168-182. http://dx.doi.org/10.1016/S0022-1694(01)00403-6

Durán Zuazo, V. H., Rodríguez Pleguezuelo, C.,R., Martin Peinado, F. J., de Graaff, J., Francia Martínez, J. R., \& Flanagan, D. C. (2011). Environmental impact of introducing plant covers in the taluses of terraces: Implications for mitigating agricultural soil erosion and runoff. Catena, 84(1-2), 79-88. http://dx.doi.org/10.1016/j.catena.2010.10.004

Ekholm, P., \& Lehtoranta, J. (2012). Does control of soil erosion inhibit aquatic eutrophication? Journal of environmental management, 93(1), 140-146. http://dx.doi.org/10.1016/j.jenvman.2011.09.010

Leong, W. C. (2007). Study On Malaysian Urban Rainfall-Runoff Characteristics: Case Study Of Sungai Kayu Ara, Damansara, Selangor. Universiti Sains Malaysia.

Peng, T., \& Wang, S. (2012). Effects of land use, land cover and rainfall regimes on the surface runoff and soil loss on karst slopes in southwest China. Catena, 90, 53-62. http://dx.doi.org/10.1016/j.catena.2011.11.001

Preuss, P. (2007). Erosion and deposition constitute a net carbon sink. Retrieved from http://www.lbl.gov/Science-Articles/Archive/sabl/2007/Apr/05-erosion.html

Rijsdijk, A. L., Bruijnzeel, S., \& Sutoto, C. K. (2007). Runoff and sediment yield from rural roads, trails and settlements in the upper Konto catchment, East Java, Indonesia. Geomorphology, 87(1), 28-37. http://dx.doi.org/10.1016/j.geomorph.2006.06.040

Samani, J. M., \& Kouwen, N. (2002). Stability and erosion in grassed channels. Journal of Hydraulic Engineering, 128(1), 40-45. http://dx.doi.org/10.1061/(ASCE)0733-9429(2002)128:1(40)

Sekitar, J. A. (1996). Guidelines for the Prevention \& Control of Soil Erosion \& Siltation in Malaysia. K Lumpur.

Toy, T. J., Foster, G. R., \& Renard, K. G. (2002). Soil erosion: Processes, prediction, measurement, and control. Wiley.

Wilson, B. (2012). Retrieved from www.laspilitas.com

Yahyapour, S., Golshan, A., \& Ghazali, A. H. B. (2013). Removal of Total Suspended Solids and Turbidity within Experimental Vegetated Channel: Optimization through Response Surface Methodology. Journal of Hydro-Environment Research, in Press. http://dx.doi.org/10.1016/j.jher.2013.03.004

Ziegler, A. D., \& Giambelluca, T. W. (1997). Importance of rural roads as source areas for runoff in mountainous areas of northern Thailand. Journal of Hydrology, 196(1-4), 204-229. http://dx.doi.org/10.1016/S0022-1694(96)03288-X

\section{Copyrights}

Copyright for this article is retained by the author(s), with first publication rights granted to the journal.

This is an open-access article distributed under the terms and conditions of the Creative Commons Attribution license (http://creativecommons.org/licenses/by/3.0/). 